\title{
[NOT THE TREATS OF QUINCE BLOSSOMS. IN THIS RAINY
}

CYCLE THE YARDS]

not the treats of quince blossoms. in this rainy cycle the yards are so much muck. levees do not so much break as buckle

we would let the river baptize and afterward: so relieved of pressures the earth could slide back into place: the houses slide back into houses and the river a river perhaps: a change in its squiggle. new bolo tie

we have been hit worse. have let waters reserve the next county as a chained hound. a second coming. but with so few human casualties the boating became a lark. it wash away, we say, all this business

and so we scrap: this the little chotchke we salvaged from the last great storm a token floats up in the night. and what bauble shrieks to us among the darkest rushes

\section{[IN THE NEW GENESIS: A PART OF HIS SKELETON BECAME ME. SHAPED ME]}

in the new genesis: a part of his skeleton became me. shaped me me as womb trembles forth. me wifeless with 300,000 retro sons me of no husband girdled and they to no spouse parcelled: salt pillars

must my skull be hut for them all? at night the anvils sing bingbong them kids is pounding out more kids. listen: the dna clinks its chainmail rickety ark of my body cannot hold. doves cannot land here 